\title{
PERKEMBANGAN KONSUMSI TERIGU DAN PANGAN OLAHANNYA DI INDONESIA 1993-2005
}

\author{
(Trend of Wheat Flour and Its Processed Product Consumption in Indonesia)
}

\author{
Hardinsyah $^{1}$ dan Leily Amalia ${ }^{1}$
}

\begin{abstract}
The objective of this study was to analyze trend of wheat flour consumption and its processed products in Indonesia since 1993 until 2005. The data used were food consumption data of Socio-economic Survey (SUSENAS) collected by Statistics Indonesia (Badan Pusat Statistik, BPS). The results showed that the wheat flour consumption and its processed products tended to increase from 1993 to 2005. The rapid increase was occurred in the period of 1993-1996 and 1999-2005. Three kinds of wheat flour-processed products that significantly increased were instant noodle, fried food and snack for children. The average consumption level of wheat flour and their processed products in 2005 in urban areas were higher than the consumption level in rural areas, namely $47.7 \mathrm{vs} .36 .3 \mathrm{~g} / \mathrm{cap} / \mathrm{d}$. Among all of the wheat flour-processed food, wheat flour based-fried food, instant noodle, and noodle with meat ball (mie bakso) were the most three popular kind of wheat flour processed products consumed by Indonesian people, 49.4, 48.6 and $44.7 \%$ respectively. The consumption pattern was relatively similar between urban and rural areas. It indicated that wheat flour processed food had already been a part of food consumption pattern of Indonesian people.
\end{abstract}

Keywords: wheat flour, wheat flour-processed food, consumption, trend of consumption, urban area, rural area.

\section{PENDAHULUAN}

\section{Latar Belakang}

Kemajuan Iptek dan globalisasi perekonomian telah mendorong pesatnya kemajuan dalam perdagangan dan inovasi pengembangan produk pangan di Indonesia, termasuk pangan olahan terigu. Berbagai inovasi, promosi dan kemudahan dalam pengolahan menyebabkan produk-produk olahan terigu semakin digemari dan permintaan semakin meningkat. Hal ini secara implisit ditunjukkan oleh semakin meningkatnya impor gandum dan terigu ke Indonesia yang mencapai pertumbuhan $8 \%$ per tahun (Purnama, 2003).

Tepung terigu memenuhi syarat untuk dijadikan vehicle (pangan pembawa) zat gizi mikro dalam program fortifikasi pangan yang ditujukan untuk melengkapi strategi mengatasi masalah anemia gizi di Indonesia (Hardinsyah, 2002). Sejak tahun 1998, pemerintah telah mewajibkan fortifikasi tepung terigu dengan zat besi, seng, vitamin B1, B2 dan asam folat melalui SK Menteri Kesehatan No. 632/ MENKES/ SK/ VI/ 98 dan SK Dirjen IKAH No. 03/ DIRJ EN-IKAH/ SK/ II/ 2002. Fortifikasi ini terutama ditujukan untuk mengatasi defisiensi zat besi sebagai salah satu dari tiga masalah gizi mikro utama di Indonesia (Hardinsyah, 2002).

Meskipun secara umum dipahami bahwa permintaan akan produk olahan terigu cenderung meningkat, tetapi informasi tentang pola konsumsi produk-produk olahan terigu bagi penduduk Indonesia di perdesaan dan perkotaan serta tingkat partisipasi (cakupan) rumahtangga pada setiap jenis pangan olahan terigu tersebut belum tersedia.

Di sisi lain, sebagai pangan sumber karbohidrat, perkembangan konsumsi terigu di Indonesia bisa menjadi indikator adanya pergeseran relatif konsumsi pangan pokok penduduk Indonesia dari beras ataupun umbiumbian menjadi terigu dan pangan olahannya.

\section{$\underline{\text { Tujuan }}$}

Penelitian ini bertujuan menganalisis perkembangan konsumsi terigu dan pangan olahan terigu penduduk Indonesia dari tahun 1993 sampai tahun 2005 di pedesaan dan perkotaan. Selain itu kajian ini ditujukan untuk menganalisis konsumsi terigu dan pangan olahan terigu penduduk berdasarkan kelompok sosial ekonomi.

\footnotetext{
1 Staf Pengajar Departemen Gizi Masyarakat, Fakultas Ekologi Manusia (FEMA), IPB.
} 


\section{METODE}

\section{Desain, Tempat dan Waktu Penelitian}

Penelitian ini merupakan penelitian non eksperimental. Penelitian dilakukan di Pusat Studi Kebijakan Pangan dan Gizi, Bogor pada bulan April 2004 dan Departemen Gizi Masyarakat, Fakultas Ekologi Manusia pada bulan April 2007.

\section{Łenis dan Cara Pengumpulan Data}

Data yang digunakan dalam analisis ini adalah data konsumsi pangan SUSENAS tahun 1993, 1996, 1999, 2002 dan 2005 yang dikumpulkan oleh Badan Pusat Statistik (BPS). BPS mengumpulkan data ini menggunakan metode recall food expenditure selama satu minggu, dengan cakupan sampel sekitar 60000 rumahtangga.

\section{Pengolahan dan Analisis Data}

Untuk tujuan kajian ini, elektronik data konsumsi SUSENAS diolah oleh analis data Susenas BPS berdasarkan protokol pengolahan data yang disiapkan oleh tim peneliti. Data yang diolah meliputi jenis dan jumlah konsumsi pangan olahan terigu serta konsumsi setiap jenis pangan olahan terigu menurut kelompok pendapatan tinggi, menengah, dan rendah, di wilayah perdesaan dan perkotaan.

Jumlah konsumsi terigu dihitung berdasarkan jumlah terigu yang dibeli untuk konsumsi rumahtangga ditambah dengan jumlah terigu yang dibeli dan dikonsumsi dalam bentuk berbagai pangan olahan terigu (dikonversikan dari pangan olahan terigu) dan dinyatakan dalam satuan g/kap/hari. Faktor konversi pangan olahan terigu terhadap terigu disajikan pada Tabel 1.

Faktor konversi dibuat dengan memperhitungkan komposisi terigu terhadap komposisi bahan total pangan olahan dimaksud. Pangan olahan terigu yang dianalisis adalah semua jenis pangan mengandung terigu yang terdapat dalam susunan daftar konsumsi pangan pada data SUSENAS, yaitu meliputi mie basah, mie instan, makaroni, roti tawar, roti manis, kue kering/ biskuit, kue basah, makanan gorengan, mie bakso, mie instan dan makanan ringan anak. Tingkat partisipasi atau cakupan konsumen dihitung berdasarkan persentase ru- mahtangga yang mengonsumsi setiap jenis pangan olahan terigu.

Tabel 1. Faktor Konversi Terigu dari Pangan Olahan Terigu

\begin{tabular}{|c|l|c|}
\hline No & \multicolumn{1}{|c|}{ Pangan Olahan } & \% Terigu \\
\hline 1 & Tepung Terigu & 1.00 \\
\hline 2 & Mie Basah & 0.33 \\
\hline 3 & Mie Instan & 0.92 \\
\hline 4 & Makaroni & 0.92 \\
\hline 5 & Roti Tawar & 0.68 \\
\hline 6 & Roti Manis & 0.68 \\
\hline 7 & Kue Kering/ Biskuit & 1.00 \\
\hline 8 & Kue Basah & 0.47 \\
\hline 9 & Makanan Gorengan & 0.25 \\
\hline 10 & Mie Bakso & 0.33 \\
\hline 11 & Makanan Ringan anak & 0.92 \\
\hline
\end{tabular}

\section{HASIL DAN PEMBAHASAN}

\section{Perkembangan Konsumsi Terigu}

Perkembangan jumlah rata-rata konsumsi terigu penduduk Indonesia pada tahun 1993, 1996, 1999, 2002, dan 2005 disajikan pada Gambar 1.

Dari gambar tersebut terlihat bahwa konsumsi terigu di Indonesia dari tahun ke tahun cenderung meningkat, kecuali dari tahun 1996 ke tahun 1999 mengalami penurunan. Jumlah konsumsi rata-rata tertinggi terjadi pada tahun 2005, baik di perkotaan maupun di perdesaan, yaitu masing-masing $31.5 \mathrm{~g} / \mathrm{kap} /$ hari dan $24.0 \mathrm{~g} / \mathrm{kap} / \mathrm{hari}$. Adapun jumlah konsumsi rata-rata terendah terjadi pada tahun 1993, yaitu $7.8 \mathrm{~g} / \mathrm{kap} /$ hari di perkotaan dan $3.3 \mathrm{~g} / \mathrm{kap} / \mathrm{hari}$ di perdesaan. Secara umum jumlah konsumsi terigu di perkotaan lebih tinggi dibandingkan konsumsi di perdesaan pada setiap tahun yang diamati.

Perkembangan konsumsi terigu per tahun ditunjukkan pada Tabel 2. Peningkatan pesat terutama terjadi dari tahun 1993 ke tahun 1996, yaitu dengan laju perkembangan $85.3 \%$ per tahun, sedangkan peningkatan dari tahun 1999 ke tahun 2002 dan dari tahun 2002 ke tahun 2005 jauh lebih kecil, yaitu masingmasing $13.6 \%$ dan $8.6 \%$ per tahun. Adapun laju penurunan konsumsi terigu dari tahun 1996 ke tahun 1999 juga relatif kecil, yaitu -3.1\% per tahun. Secara keseluruhan laju peningkatan konsumsi terigu dari tahun 1993 ke tahun 2005 cukup besar, yaitu mencapai 26.1\% per tahun. 


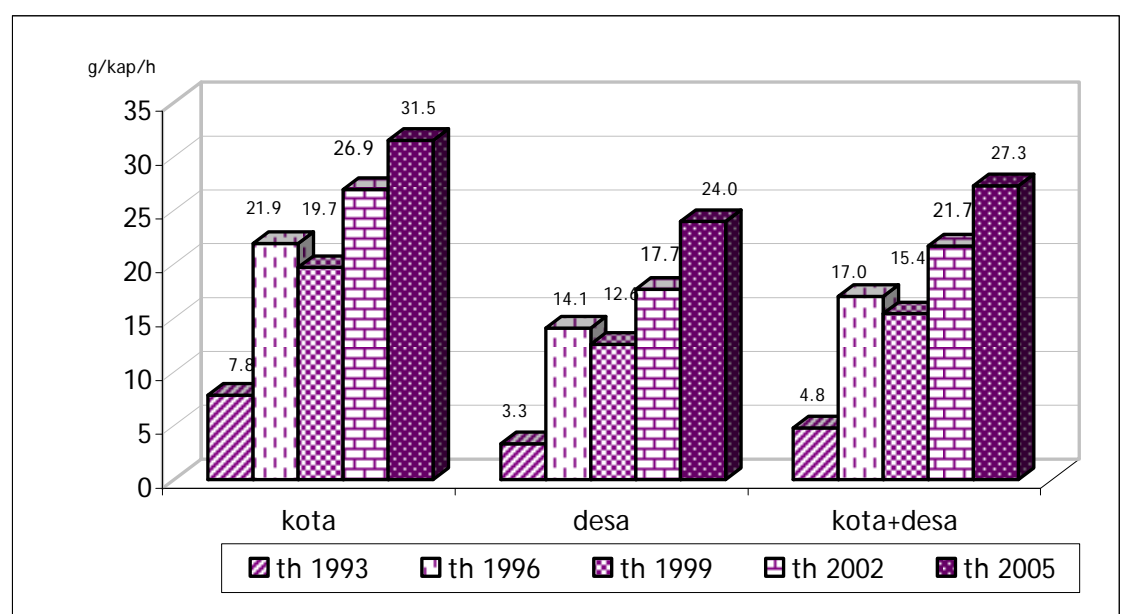

Gambar 1. Perkembangan Konsumsi Tepung Terigu Rata-rata Penduduk Indonesia di Perkotaan dan Perdesaan Tahun 1993-2005 (Susenas)

Tabel 2. Laju Tahunan Perkembangan Konsumsi Terigu di Perkotaan, Pedesaan, serta Perkotaan dan Pedesaan.

\begin{tabular}{|c|c|c|c|}
\hline Tahun & Kota & Desa & Kota+Desa \\
\hline $1993-1996$ & $59.0 \%$ & $106.4 \%$ & $85.3 \%$ \\
\hline $1996-1999$ & $-3.3 \%$ & $-3.5 \%$ & $-3.1 \%$ \\
\hline $1999-2002$ & $12.2 \%$ & $13.4 \%$ & $13.6 \%$ \\
\hline $2002-2005$ & $6.1 \%$ & $12.5 \%$ & $8.6 \%$ \\
\hline Rata-rata & $\mathbf{1 8 . 5 \%}$ & $\mathbf{3 2 . 2} \%$ & $\mathbf{2 6 . 1 \%}$ \\
\hline
\end{tabular}

Fluktuasi perkembangan konsumsi terigu di wilayah perkotaan dan pedesaan adalah sama, yaitu cenderung meningkat, kecuali dari tahun 1996 ke tahun 1999 yang mengalami penurunan. Secara keseluruhan laju perkembangan konsumsi terigu per tahun di perdesaan (32.2\%) lebih besar dibandingkan dengan perkembangan konsumsi per tahun di perkotaan (18.5\%).

Laju perkembangan konsumsi terigu yang tinggi dari tahun 1993 ke tahun 1996 besar kemungkinan disebabkan oleh adanya subsidi dan kemudahan dalam hal kebijakan dari pemerintah terhadap produsen pengolahan terigu. Adapun penurunan laju konsumsi terigu dari tahun 1996 ke tahun 1999 besar kemungkinan disebabkan oleh krisis ekonomi Indonesia yang mencapai puncaknya pada tahun 1997 serta adanya deregulasi kebijakan perdagangan oleh pemerintah yang menetapkan bea masuk impor gandum sebesar $5 \%$ pada tahun 1998. Peningkatan konsumsi terigu dari tahun 1999 ke tahun 2002 dan dari tahun 2002 ke tahun 2005 menunjukkan telah terjadi peningkatan daya beli rumahtangga terhadap terigu dan pangan olahannya.
Meskipun jumlah konsumsi terigu di pedesaan lebih rendah dibandingkan di perkotaan (Gambar 1), laju konsumsi terigu di perdesaan lebih tinggi dibandingkan laju konsumsi di perkotaan (Tabel 2). Hal ini menunjukkan bahwa pangan olahan terigu semakin digemari oleh penduduk perdesaan. Meskipun demikian, karena daya beli penduduk perkotaan lebih tinggi dibandingkan penduduk perkotaan, maka secara kuantitas tingkat konsumsi terigu dan pangan olahannya pada penduduk perkotaan lebih besar dibandingkan penduduk perdesaan.

\section{Perkembangan Konsumsi Pangan Olahan Terigu}

Perkembangan dan laju konsumsi terigu dan pangan olahan terigu rata-rata penduduk Indonesia dari tahun 1993 sampai dengan tahun 2005 disajikan pada Gambar 2 dan Tabel 3. Sebagaimana konsumsi terigu, konsumsi pangan olahan terigu pada umumnya juga mengalami kenaikan dari tahun 1993 sampai tahun 1996 tetapi kemudian mengalami penurunan dari tahun 1996 ke tahun 1999 akibat krisis ekonomi, kemudian menaik kembali dari tahun 1999 ke tahun 2002. Meskipun demikian, kondisi tersebut tidak terjadi pada produk makanan gorengan dan makanan ringan anak, yaitu masing-masing mengalami laju konsumsi 3. 0 dan 9.3\% tahun (Tabel 3).

Konsumsi makanan gorengan yang tidak menurun pada masa krisis ekonomi kemungkinan disebabkan oleh konsumsi makanan gorengan di Indonesia yang telah membudaya. Di samping itu, harga makanan gorengan cenderung lebih murah dibandingkan pangan olahan terigu lainnya sehingga pada saat krisis pangan tersebut menjadi pilihan pengganti pangan olahan terigu lainnya yang biasa dikonsumsi saat sebelum krisis. Konsumsi makanan ringan 
anak yang cenderung meningkat meski pada masa krisis ekonomi kemungkinan disebabkan oleh inovasi produk yang semakin beragam dari segi citarasa dan kemasan, disukai, iklan atau promosi yang gencar, serta harga yang terjangkau.

Dari gambar 2 juga terlihat bahwa pangan olahan terigu yang paling banyak dikonsumsi pada setiap tahun pengamatan (kecuali tahun 1993) secara berturut-turut adalah makanan gorangan (>7 g/ kap/hari), mie instan (>4 g/ kap/hari), dan kue basah (>3 g/kap/ hari). Hal ini menunjukkan bahwa ketiga jenis makanan tersebut merupakan makanan yang digemari penduduk Indonesia.
Dilihat dari segi perkembangannya, makanan gorengan dan kue basah memiliki laju peningkatan konsumsi yang rendah, yakni masing-masing $2.8 \%$ tahun dan $0.3 \%$ tahun. Lain halnya dengan mie instan, produk ini mengalami perkembangan yang sangat pesat, (ratarata $17.0 \%$ tahun), terutama terjadi dalam kurun tahun 1993-1996 yang mencapai 65.3\% tahun. Hal ini kemungkinan disebabkan oleh adanya inovasi citarasa produk dan perkembangan jumlah produsen yang menyebabkan permintaan dan konsumsi produk mie instan meningkat pesat (Tabel 3).

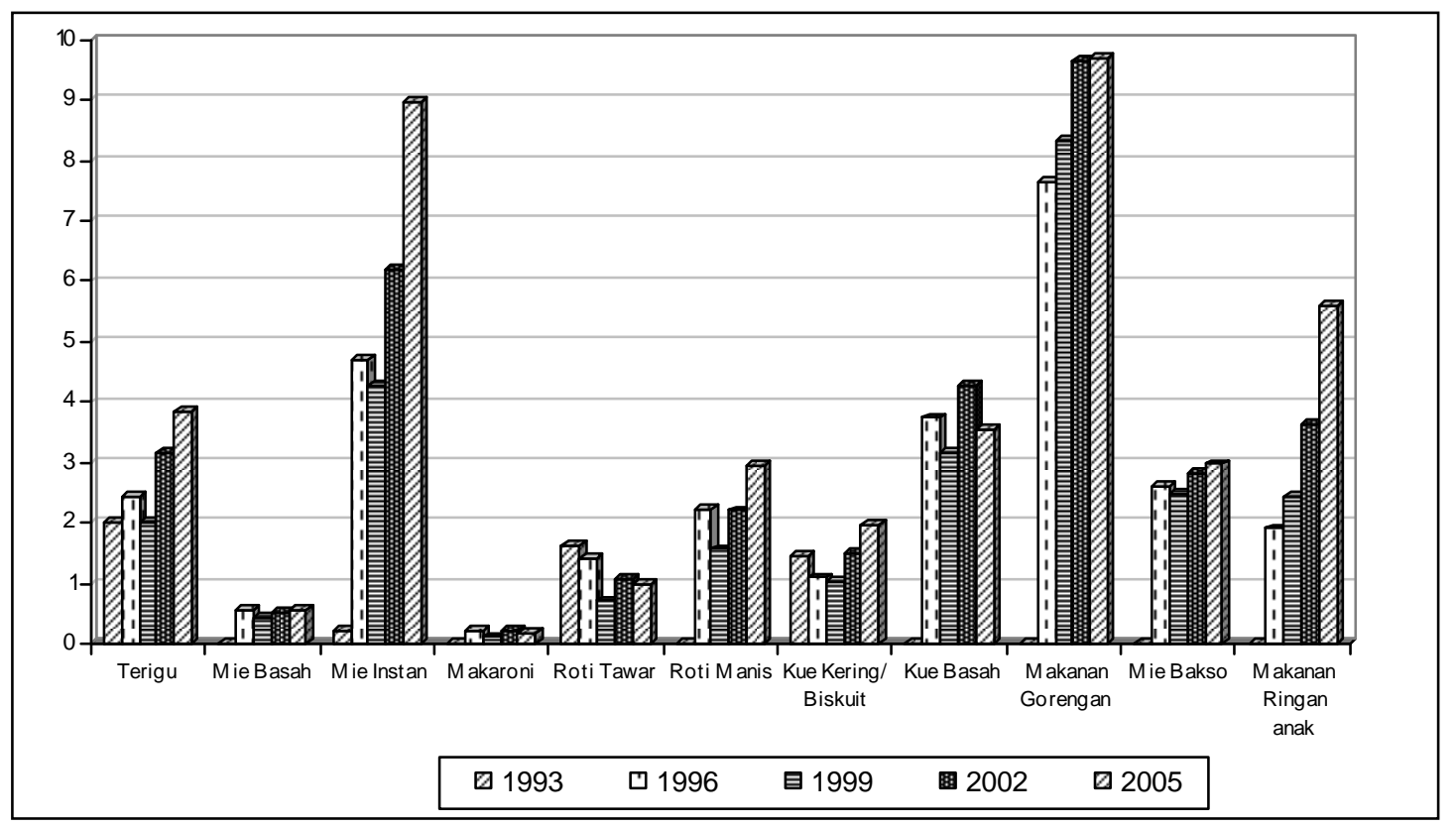

Gambar 2. Perkembangan Konsumsi Terigu dan Berbagai Pangan Olahan Terigu (g/ kap/hari) Penduduk Indonesia (rata-rata desa dan kota) tahun 1993 - 2005

Tabel 3. Laju Perkembangan Tahunan (dalam persen) Konsumsi Terigu dan Pangan Olahan Terigu Penduduk Indonesia (Rata-rata Perkotaan dan Perdesaan)

\begin{tabular}{|l|r|r|r|r|r|}
\hline \multirow{2}{*}{\multicolumn{1}{c|}{ J enis pangan }} & \multicolumn{5}{|c|}{ Rentang tahun } \\
\cline { 2 - 7 } & $\mathbf{1 9 9 3 - 1 9 9 6}$ & $\mathbf{1 9 9 6 - 1 9 9 9}$ & $\mathbf{1 9 9 9 - 2 0 0 2}$ & $\mathbf{2 0 0 2 - 2 0 0 5}$ & Rata-rata \\
\hline Terigu & 7.1 & -5.9 & 19.3 & 7.4 & 7.0 \\
\hline Mie Basah & 0 & -8.3 & 7.1 & 3.3 & 0.7 \\
\hline Mie Instan & 653.3 & -3.1 & 14.9 & 14.9 & 170.0 \\
\hline Makaroni & 0 & -15.6 & 30.8 & -9.5 & 1.9 \\
\hline Roti Tawar & -4.4 & -16.7 & 16.6 & -2.3 & -1.7 \\
\hline Roti Manis & 0 & -10.1 & 13.8 & 11.3 & 5.0 \\
\hline Kue Kering/ Biskuit & -8.5 & -1.3 & 14.9 & 10.2 & 3.8 \\
\hline Kue Basah & 0 & -4.9 & 11.6 & -5.8 & 0.3 \\
\hline Makan Gorengan & 0 & 3.0 & 5.2 & 0.2 & 2.8 \\
\hline Mie Bakso & 0 & -1.7 & 4.7 & 1.8 & 1.6 \\
\hline Makanan Ringan anak & 0 & 9.3 & 16.8 & 17.7 & 14.6 \\
\hline
\end{tabular}


Pangan lain yang memiliki laju perkembangan tinggi adalah makanan ringan anak yang mengalami laju rata-rata $14.6 \%$ tahun (Tabel 3). Hal ini besar kemungkinan akibat dari perkembangan ilmu dan teknologi pengolahan pangan yang menawarkan berbagai jenis produk makanan ringan dengan berbagai jenis dan citarasa yang banyak digemari masyarakat, terutama anak-anak.

Dari Gambar 2 dan Tabel 3 terlihat bahwa pangan olahan terigu yang mengalami peningkatan pesat dalam tiga tahun terakhir (dari 2002 sampai 2005) adalah makanan ringan anak dan mie instan. Kedua jenis pangan ini merupakan pangan yang pada umumnya diproduksi oleh industri pangan dalam skala cukup besar. Hal ini bisa jadi merupakan indikasi dari adanya perkembangan dalam teknologi pengolahan pangan

\section{Konsumsi Terigu dan Pangan Olahan Terigu Tahun 2005}

Konsumsi terigu dan pangan olahan terigu rata-rata penduduk Indonesia di perkotaan dan perdesaan tahun 2005 disajikan pada Tabel 4. Dari tabel tersebut terlihat bahwa konsumsi terigu maupun pangan olahan terigu penduduk di perkotaan lebih tinggi dibandingkan perdesaan. Secara keseluruhan, rata-rata konsumsi terigu dan pangan olahan terigu penduduk perkotaan adalah $47.7 \mathrm{~g} / \mathrm{kap} / \mathrm{hari}$ sedangkan konsumsi di perdesaan adalah 36.3 $\mathrm{g} / \mathrm{kap} /$ hari dengan rata-rata (desa dan kota) sebesar $41.2 \mathrm{~g} / \mathrm{kap} /$ hari. Konsumsi setiap jenis pangan olahan terigu penduduk perkotaan le- bih besar dibandingkan konsumsi penduduk perdesaan. Konsumsi yang tinggi pada penduduk perkotaan tersebut kemungkinan disebabkan oleh kemudahan akses penduduk perkotaan terhadap aneka pangan olahan terigu, baik dari segi akses ekonomi maupun dari segi akses pasar.

Pangan olahan terigu yang paling banyak dikonsumsi penduduk Indonesia pada tahun 2005 baik di perkotaan maupun di perdesaan adalah makanan gorengan (rata-rata $9.7 \mathrm{~g} / \mathrm{kap}$ / hari) dan mie instan (rata-rata $9.0 \mathrm{~g} / \mathrm{kap} /$ hari). Berdasarkan wilayah, konsumsi kedua jenis pangan tersebut juga tinggi baik di perkotaan maupun perdesaan, yaitu masingmasing 10.6 dan $9.0 \mathrm{~g} / \mathrm{kap} /$ hari (makanan gorengan) dan 10.7 dan 7.6 gkap/hari (mie instan). Hal ini menunjukkan bahwa preferensi penduduk di perkotaan maupun di perdesaan terhadap pangan olahan terigu relatif sama.

Tingginya konsumsi makanan gorengan menunjukkan bahwa makanan tradisional seperti pisang goreng, bakwan, ubi goreng dan sebagainya merupakan makanan yang digemari karena mudah diperoleh dan harga terjangkau. Tingginya konsumsi mie instan menunjukkan gaya hidup serba praktis yang telah membudaya dan inovasi citarasa produk yang semakin beragam. Sebagai makanan yang bisa disajikan dalam waktu kurang dari 10 menit, mie instan telah menjadi menu sarapan ataupun makanan selingan yang diminati masyarakat terutama di perkotaan.

Tabel 4. Konsumsi Terigu dan Pangan Olahan Berbasis Terigu Penduduk Indonesia di Pedesaan, PerkotaanTahun 2005 (g/ kap/h).

\begin{tabular}{|c|c|c|c|}
\hline Tahun & Kota & Desa & Kota+Desa \\
\hline Terigu & 3.9 & 4.0 & 3.9 \\
\hline Mie Basah & 0.7 & 0.4 & 0.6 \\
\hline Mie Instan & 10.7 & 7.6 & 9.0 \\
\hline Makaroni & 0.2 & 0.1 & 0.2 \\
\hline Roti Tawar & 1.5 & 0.6 & 1.0 \\
\hline Roti Manis & 3.4 & 2.6 & 2.9 \\
\hline Kue Kering/ Biskuit & 2.4 & 1.6 & 2.0 \\
\hline Kue Basah & 3.8 & 3.4 & 3.5 \\
\hline Makan Gorengan & 10.6 & 9.0 & 9.7 \\
\hline Mie Bakso & 4.0 & 2.1 & 3.0 \\
\hline Makanan Ringan anak & 6.5 & 4.8 & 5.6 \\
\hline Jumlah & 47.7 & 36.3 & 41.2 \\
\hline
\end{tabular}




\section{Persentase Penduduk yang Mengkonsumsi Pangan Olahan Terigu}

Berdasarkan data tahun 2002 (data yang lengkap diolah), pangan yang paling digemari penduduk Indonesia berturut-turut adalah makanan gorengan (49.4\%), mie instan (48.6\%), mie bakso (44.7\%) dan kue basah (39.3\%) (Gambar 3). Hal tersebut sebanding dengan tingkat konsumsi penduduk atas makananmakanan tersebut (lihat Gambar 2).
Pangan olahan terigu yang paling digemari penduduk perkotaan adalah mie bakso (58.3\%) dan mie instan (57.1\%), sedangkan di perdesaan adalah makanan gorengan (45.8\%) dan mie instan (41.8\%). Pangan yang rendah tingkat konsumsinya, baik di pedesaan maupun di perkotaan adalah makaroni, yaitu masingmasing dikonsumsi hanya oleh $1.7 \%$ dan $2.2 \%$ penduduk. Hal tersebut kemungkinan karena jenis makanan dengan menggunakan bahan makaroni masih terbatas (Gambar 4).

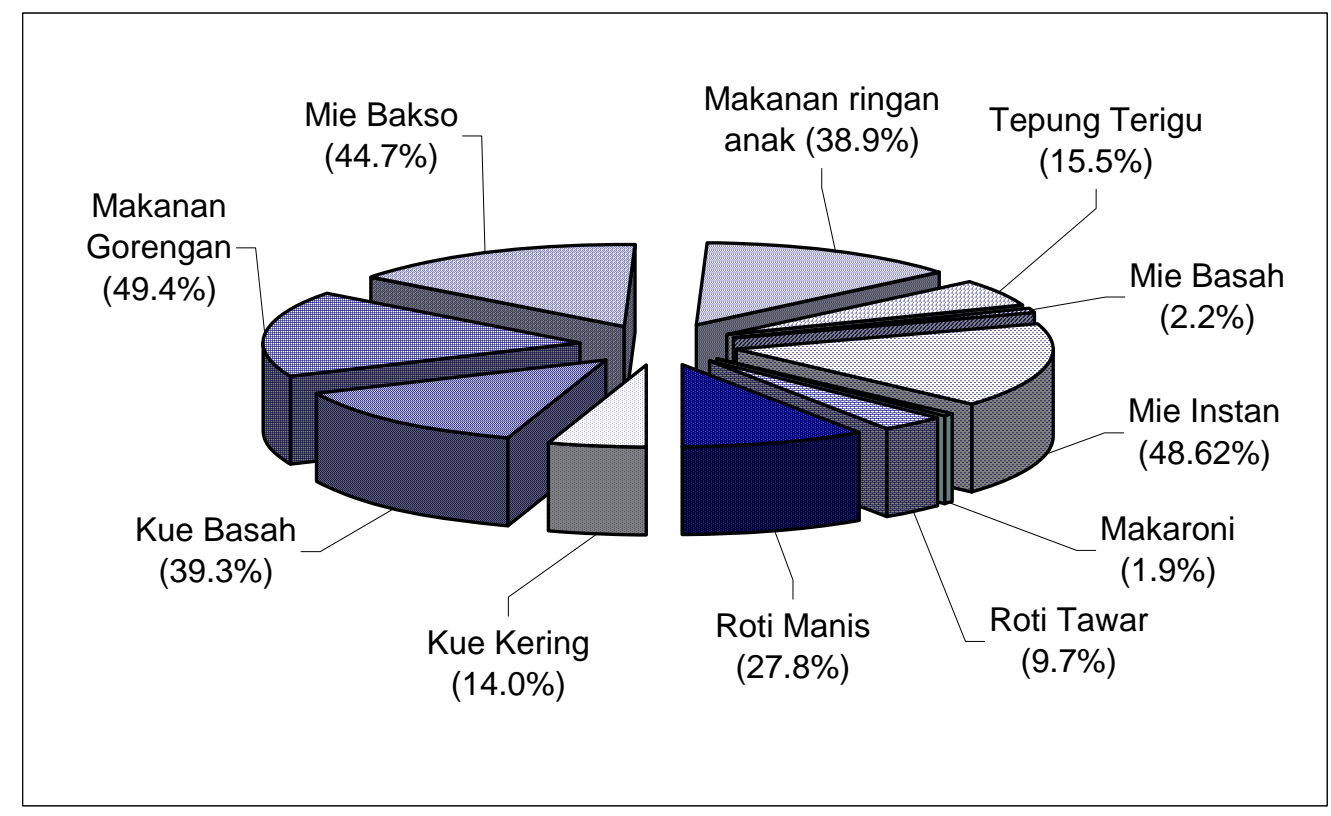

Gambar 3. Persentase Penduduk Indonesia yang Mengkonsumsi Pangan Olahan Terigu tahun 2002

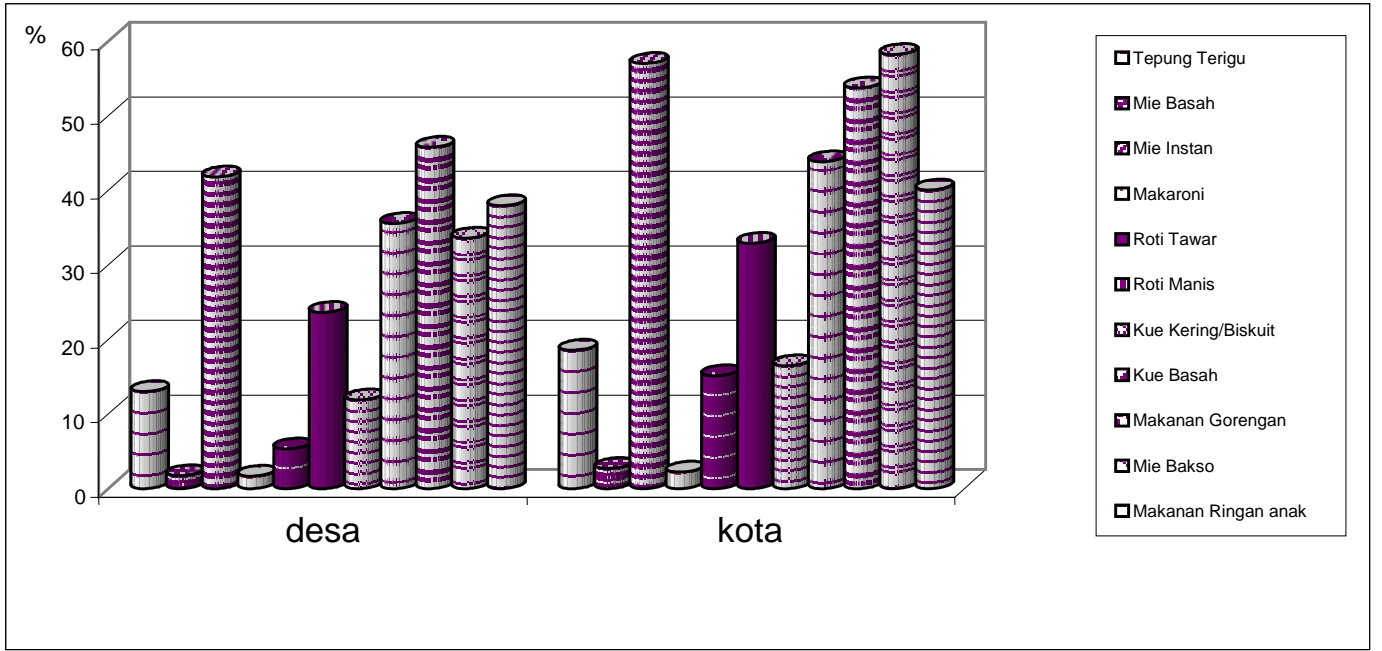

Gambar 4. Persentase Penduduk yang Mengkonsumsi Pangan Olahan Terigu menurut Strata Wilayah Tempat Tinggal (Perdesaan dan Perkotaan) 
Tabel 5. Kontribusi Gizi Mikro terhadap AKG yang Berasal dari Konsumsi Terigu dan Pangan Olahannya

\begin{tabular}{|l|c|c|c|c|}
\hline \multirow{2}{*}{ Zat gizi } & \multicolumn{3}{|c|}{ Konsumsi dari terigu } & \multirow{2}{*}{ \%AKG* } \\
\cline { 2 - 4 } & Alami & Fortifikasi & Total & \\
\hline Besi (mg) & 0.49 & 2.06 & 2.6 & 9.8 \\
\hline Seng (mg) & 0.33 & 1.24 & 1.6 & 14.4 \\
\hline Folat (ug) & 3.71 & 82.40 & 86.1 & 21.5 \\
\hline
\end{tabular}

*Dihitung terhadap AKG $2000 \mathrm{Kal}$

\section{Konsumsi Gizi Mikro dari Terigu dan Pangan Olahan Terigu}

Sebagaimana telah diungkapkan sebelumnya, sejak tahun 1999 pemerintah melalui SK Menteri Kesehatan dan SK Dirjen IKAH tentang SNI tepung terigu (tahun 2002), telah mewajibkan (mandatory) para produsen untuk memfortifikasi tepung terigu dengan beberapa jenis gizi mikro, yaitu zat besi (50 ppm), seng (30 ppm), dan folat (2 ppm).

Hingga saat ini hanya ada 5 pabrik penggilingan terigu di Indonesia, yaitu Bogasari (di Jakarta dan Surabaya), Berdikari Sari Utama (Ujung Pandang), Pangan Mas Inti Persada (Cilacap), serta Sriboga Raturaya (Semarang). Tepung terigu yang beredar di pasaran Indonesia merupakan produksi dari keempat produsen tersebut. Kewajiban fortifikasi telah dilaksanakan oleh kelima pabrik penggilingan tepung terigu dengan waktu pelaksanaan yang bervariasi, yaitu Bogasari Flour Mills-J akarta pada bulan Januari 1999, Bogasari Flour MillsSurabaya pada Februari 1999, Pangan Mas Inti Persada pada Mei 1999, Sriboga Raturaya pada J uli 1999, dan Berdikari Flour Mills pada bulan September 1999. Dengan demikian, dapat diasumsikan bahwa terigu dan pangan olahan terigu yang dikonsumsi pada tahun 2005 (dan tahun 2002) merupakan terigu yang telah difortifikasi besi, seng, dan folat.

Dengan memperhitungkan kandungan zat fortifikan minimal yang diwajibkan di atas dan kandungan zat gizi alami pada tepung terigu (sebelum fortifikasi) serta konsumsi tepung terigu rata-rata penduduk Indonesia tahun 2005 (Tabel 4, yaitu $41.2 \mathrm{~g} / \mathrm{kap} / \mathrm{hari}$ ), maka dapat diketahui kontribusi konsumsi zat besi, seng dan folat yang berasal dari terigu dan pangan olahannya terhadap Angka Kecukupan Gizi yang Dianjurkan (Tabel 5).

Dari tabel tersebut terlihat bahwa konsumsi terigu pangan olahan terigu memberikan kontribusi terhadap AKG zat besi, seng, dan folat masing-masing $9.8 \% 14.4 \%$ dan $21.5 \%$

\section{KESIMPULAN}

1. Konsumsi tepung terigu penduduk Indonesia dari tahun 1993 sampai tahun 1996 mengalami kenaikan pesat (dari 5.5 menjadi $17.0 \mathrm{~g} / \mathrm{kap} / \mathrm{hari}$ ), sedangkan dari tahun 1996 sampai tahun 1999 mengalami penurunan (menjadi $15.4 \mathrm{~g} / \mathrm{kap} / \mathrm{hari}$ ). Kemudian meningkat kembali dari tahun 1999 sampai tahun 2002 (menjadi $21.7 \mathrm{~g} / \mathrm{kap} /$ hari), dan juga dari tahun 2002 sampai tahun 2005 (menjadi $27.3 \mathrm{~g} / \mathrm{kap} / \mathrm{hari}$ ).

2. Pola konsumsi pangan produk olahan terigu di pedesaan relatif sama dengan di perkotaan; perbedaannya adalah dalam kuantitas yang dikonsumsi. Konsumsi pangan produk olahan terigu di perkotaan lebih tinggi dibanding di perdesaan.

3. Makanan gorengan olahan terigu dan mie instan merupakan pangan olahan terigu yang paling banyak dikonsumsi penduduk, baik dilihat dari segi kuantitas yang dikonsumsi (masing-masing 9.6 dan $6.4 \mathrm{~g} / \mathrm{kap} /$ hari) maupun dilihat dari persentase penduduk yang mengkonsumsinya (masingmasing $49.4 \%$ dan $48.6 \%$ ).

4. Diantara berbagai jenis pangan olahan terigu, makanan gorengan dan makanan ringan anak merupakan produk pangan olahan terigu yang meningkat pesat pertumbuhan konsumsinya.

\section{UCAPAN TERIMA KASIH}

Ucapan terima kasih disampaikan kepada Bapak Aryogo dan Bapak Munawar yang telah memfasilitasi penulis untuk akses pada data SUSENAS 2002 dan kepada Ibu Dr. Ir. Yayuk F. Baliwati yang telah menfasilitasi data SUSENAS 2005. 


\section{DAFTAR PUSTAKA}

BPS. 1993. Pengeluaran untuk Konsumsi Penduduk Indonesia 1993 : Survei Sosial Ekonomi Nasional. Biro Pusat Statistik, Jakarta.

BPS. 1996. Pengeluaran untuk Konsumsi Penduduk Indonesia 1996 : Survei Sosial Ekonomi Nasional. Biro Pusat Statistik, Jakarta.

BPS. 1999. Pengeluaran untuk Konsumsi Penduduk Indonesia 1999: Survei Sosial Ekonomi Nasional. Badan Pusat Statistik, Jakarta.

Hardinsyah. 2002. Country Invesment Plan : Food Fortification in Indonesia. Bogor Agricultural University, National Fortification Commission, Directorate General of Public Health, Directorate General of Agro based Industry and Chemical, Deputy of Food Safety and Hazardous Substances, Asian Development Bank and the Keystone Center USA, J akarta.
Hardinsyah. 2002. Strategi Fortifikasi Pangan. Prosiding Kongres PERSAGI, 8-11 Juli 2002. PERSAGI, J akarta.

Lotfi M et al., 1996. Micronutrient Fortification of Foods: Current practices, research, and opportunities. International Development Research Centre (IDRC)/International Agriculture Centre (IAC), Ottawa, Ontario, Canada.

OMNI, ROCHE, USAID, 1996. Fortification Basics. OMNI, ROCHE, USAID, Canada.

Purnama P. Fortifikasi Tepung Terigu di Indonesia dalam Hardinsyah, Amalia L dan Setiawan B. 2002. Fortifikasi Tepung Terigu dan Minyak Goreng. Pusat Studi Kebijakan Pangan dan Gizi-IPB, Komisi Fortifikasi Nasional dan ADB-Manila dan Keystone Center-USA.

Untoro R. 2002. Masalah Gizi Mikro di Indonesia dan Potensi Penanggulangannya daIam Hardinsyah, Amalia L \& Setiawan B. 2002. Fortifikasi Tepung Terigu dan Minyak Goreng. Pusat Studi Kebijakan Pangan dan Gizi-IPB, Komisi Fortifikasi Nasional dan ADB-Manila dan Keystone Center-USA. 